Images in...

\title{
The odd fate of a chicken dinner
}

\author{
Naomi Jane Wright, ${ }^{1}$ Francesco Prete, ${ }^{1}$ Tom Wiggins, ${ }^{2}$ James Crosbie ${ }^{2}$ \\ 1Department of General Surgery, University College Hospital London, London, UK; \\ 2Department of Colorectal Surgery, University College London Hospital, London, UK
}

Correspondence to Mr Tom Wiggins, thomas.wiggins@hotmail.co.uk

\section{DESCRIPTION}

A 75-year-old woman presented with a 3-day history of right iliac fossa (RIF) pain and vomiting. On examination she looked well, had normal observations, but exquisite tenderness in the RIF. Her medical history included open anterior resection for sigmoid adenocarcinoma, adhesiolysis and bilateral hip arthroplasties. CT abdomen/pelvis

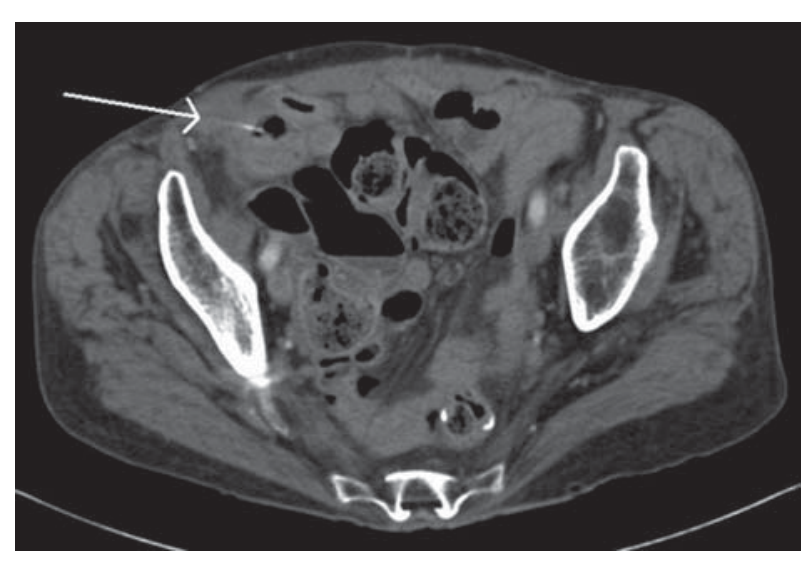

Figure 1 Axial CT showing the chicken bone protruding through the caecal wall (arrow).
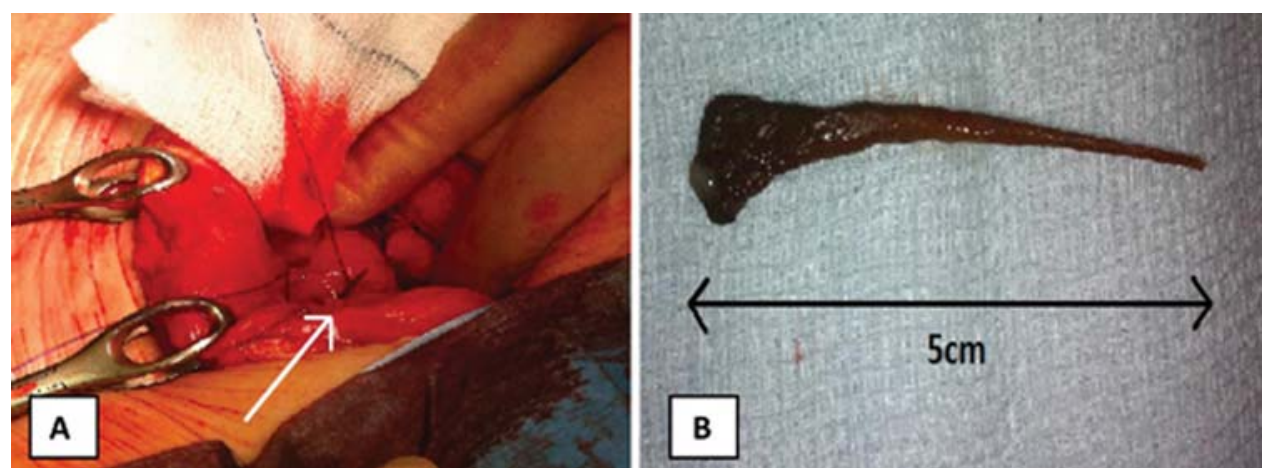

Figure 2 A) Intraoperative image of the chicken bone protruding through the caecal wall (arrow). B) Chicken bone. reported a metallic streak artefact related to the bilateral hip arthroplasties in the RIF, no evidence of perforation and faecal loading'. She was initially managed conservatively. The persistence and intensity of her pain were disproportionate to the CT findings, and imaging review highlighted that the previously reported metallic streak could be a foreign body (figure 1). Ultrasound confirmed a linear density within the caecum extending through the wall with localised free fluid and gas. At laparotomy a 5 $\mathrm{cm}$ chicken bone was found protruding through the caecal wall; it was removed via enterotomy (figure 2). The patient made a full recovery. Diagnosis of foreign body bowel perforation requires a high degree of suspicion. Most foreign bodies pass through the gastrointestinal tract without consequence; however fish bones, chicken bones, toothpicks and cocktail sticks have been known to cause perforation. ${ }^{1-3}$ Most people do not remember ingesting the object. ${ }^{1}$ Presenting features can include: peritonitis, obstruction, per rectal bleeding, abscess or enteric fistula formation. ${ }^{1-3}$ Risk factors include extremes of age, dentures, alcoholism, mental illness and underlying bowel pathology such as diverticular disease or intestinal strictures. ${ }^{1}$ Perforation occurs most often at points of narrowing or angulation and the presence of adhesions may have contributed in this case. 


\section{BMJ Case Reports}

\section{Learning points}

- Be aware of foreign body perforation as a differential diagnosis in patients presenting with an acute abdomen, particularly in those who are at the extremes of age, wear dentures, have a high alcohol intake, mental illness, or a medical history of bowel pathology.

- Patients will commonly not recall ingesting the foreign body so do not rely on this as part of the history.

- $\mathrm{CT}$ is considered to be the most useful imaging to determine the preoperative diagnosis and associated complications, however as shown in this case ultrasound can also be a valuable investigation.
Competing interests None.

Patient consent Obtained.

\section{REFERENCES}

1. Akhtar S, McElvanna N, Gardiner KR, et al. Bowel perforation caused by swallowed chicken bones-a case series. Ulster Med J 2007;76:37-8.

2. Li SF, Ender K. Toothpick injury mimicking renal colic: case report and systematic review. J Emerg Med 2002;23:35-8.

3. Doganay M, Metin E, Doganay M. Acute abdomen due to a foreign body in the urinary bladder in an adolescent. J Emerg Med 2011;40:391-2.

This pdf has been created automatically from the final edited text and images.

Copyright 2012 BMJ Publishing Group. All rights reserved. For permission to reuse any of this content visit

http://group.bmj.com/group/rights-licensing/permissions.

BMJ Case Report Fellows may re-use this article for personal use and teaching without any further permission.

Please cite this article as follows (you will need to access the article online to obtain the date of publication).

Wright NJ, Prete F, Wiggins T, Crosbie J. The odd fate of a chicken dinner. BMJ Case Reports 2012;10.1136/bcr.01.2012.5588, Published XXX

Become a Fellow of BMJ Case Reports today and you can:

- Submit as many cases as you like

- Enjoy fast sympathetic peer review and rapid publication of accepted articles

- Access all the published articles

- Re-use any of the published material for personal use and teaching without further permission

For information on Institutional Fellowships contact consortiasales@bmjgroup.com

Visit casereports.bmj.com for more articles like this and to become a Fellow

Keep up to date with all published cases by signing up for an alert (all we need is your email address) http://casereports.bmj.com/cgi/alerts/etoc 